Article

\title{
Downregulation of Astrocytic Kir4.1 Potassium Channels Is Associated with Hippocampal Neuronal Hyperexcitability in Type 2 Diabetic Mice
}

\author{
Miguel P. Méndez-González 1,2,3 (D), David E. Rivera-Aponte ${ }^{1}$, Jan Benedikt ${ }^{4}$, \\ Geronimo Maldonado-Martínez ${ }^{5}$, Flavia Tejeda-Bayron ${ }^{1}$, Serguei N. Skatchkov ${ }^{1,4, *(D)}$ \\ and Misty J. Eaton 1,* \\ 1 Department of Biochemistry, Universidad Central del Caribe, Bayamón, PR 00960-6032, USA; \\ miguel.mendez3@upr.edu (M.P.M.-G.); david.rivera@uccaribe.edu (D.E.R.-A.); \\ ftejedabayron@gmail.com (F.T.-B.) \\ 2 Department of Sciences and Technology, Antilles Adventist University, Mayaguez, PR 00680, USA \\ 3 Department of Natural Sciences, University of Puerto Rico, Aguadilla, PR 00604-6150, USA \\ 4 Departments of Physiology and Biochemistry Universidad Central del Caribe, \\ Bayamón, PR 00960-6032, USA; janbenedikt79@yahoo.com \\ 5 School of Chiropractic, Universidad Central del Caribe, Bayamón, PR 00960-6032, USA; \\ geronimo.maldonado@uccaribe.edu \\ * Correspondence: sergueis64@gmail.com (S.N.S.); misty.eaton@uccaribe.edu (M.J.E.); \\ Tel.: +787-798-3001 (ext. 2057) (S.N.S.); +787-798-3001 (ext. 2034) (M.J.E.); Fax: +787-786-6285 (M.J.E.)
}

Received: 10 January 2020; Accepted: 22 January 2020; Published: 30 January 2020

Abstract: Epilepsy, characterized by recurrent seizures, affects 1\% of the general population. Interestingly, $25 \%$ of diabetics develop seizures with a yet unknown mechanism. Hyperglycemia downregulates inwardly rectifying potassium channel 4.1 (Kir4.1) in cultured astrocytes. Therefore, the present study aims to determine if downregulation of functional astrocytic Kir4.1 channels occurs in brains of type 2 diabetic mice and could influence hippocampal neuronal hyperexcitability. Using whole-cell patch clamp recording in hippocampal brain slices from male mice, we determined the electrophysiological properties of stratum radiatum astrocytes and CA1 pyramidal neurons. In diabetic mice, astrocytic Kir4.1 channels were functionally downregulated as evidenced by multiple characteristics including depolarized membrane potential, reduced barium-sensitive Kir currents and impaired potassium uptake capabilities of hippocampal astrocytes. Furthermore, CA1 pyramidal neurons from diabetic mice displayed increased spontaneous activity: action potential frequency was $\approx 9$ times higher in diabetic compared with non-diabetic mice and small EPSC event frequency was significantly higher in CA1 pyramidal cells of diabetics compared to non-diabetics. These differences were apparent in control conditions and largely pronounced in response to the pro-convulsant 4-aminopyridine. Our data suggest that astrocytic dysfunction due to downregulation of Kir4.1 channels may increase seizure susceptibility by impairing astrocytic ability to maintain proper extracellular homeostasis.

Keywords: diabetes; hyperexcitability; astrocytes; Kir4.1; hippocampus; potassium uptake

\section{Introduction}

Epilepsy, characterized by recurrent seizure episodes, is one of the most common neurological disorders [1]. However, seizures may also be provoked by electrolyte imbalance such as hyponatremia, by metabolic disturbances such as hypoglycemia or hyperglycemia, as well as by high fever and head trauma [2]. Interestingly, $25 \%$ of patients with type 2 diabetes develop seizures throughout their lives [3]. It has been reported that non-ketotic hyperglycemia patients suffered from seizures with an unknown 
cause. These seizure episodes could often be reversed by insulin or sulphonylurea compounds, indicating that hyperglycemia is a great candidate causing this phenomenon [4,5]. In addition, a recent 10 year population-based study concluded that the incidence of epilepsy was 1.50 times higher in a cohort with type 2 diabetes as compared to matched controls [6]. Although provoked seizures can be caused by both hypoglycemia and hyperglycemia [4,5,7], our main focus in this study is on hyperglycemia and the potential role of astrocytes in seizure susceptibility. In respect to the focus of the present study, it is noteworthy that hyperglycemic diabetic animal models display synaptic transmission issues such as increased latencies of visual and auditory evoked potentials, hearing problems, impaired long-term potentiation and depression in hippocampal neurons [8-10]; all with yet unknown mechanism(s).

Astrocytes are one of the major cell types in the CNS and they enwrap blood vessels and neuronal synapses. These cells are imperative for proper brain function; particularly for $\mathrm{K}^{+}$and glutamate homeostasis [11-14]. Inability of astrocytes to control $\mathrm{K}^{+}$and glutamate levels, in active synaptic areas, may contribute to epilepsy and seizures [13-15]. Astrocytes have a hyperpolarized membrane potential mainly due to the expression of inwardly rectifying potassium channels 4.1 (Kir4.1) that provide the major $\mathrm{K}^{+}$conductance [11-13,16,17]. These channels play a fundamental role in buffering excess $\mathrm{K}^{+}$released after neuronal activity and contribute to removal of excess glutamate by processes called potassium buffering and glutamate clearance, respectively $[12-14,18,19]$.

Mutation, downregulation or disruption of the Kir4.1 channel protein are causal in certain forms of human epilepsy [20-23]. Moreover, in humans, seizure susceptibility is increased by hyperosmolarity, hyponatremia and hyperglycemia, caused by both type 1 and type 2 diabetes [24,25]. In cell culture, we have shown that Kir4.1 mRNA and protein levels are downregulated in astrocytes cultured in high glucose medium (simulating uncontrolled diabetes) and down-regulation is associated with impaired $\mathrm{K}^{+}$uptake and glutamate clearance by these astrocytes [26].

The purpose of the present study was to assess astrocytic Kir4.1 channel function and correlate this with in-vitro neuronal epileptiform-like activity in diabetic mice. We utilized the $\mathrm{db} / \mathrm{db}$ type 2 diabetic mouse model which has a homozygous point mutation in the gene encoding the leptin receptor [27]. In this study, we found reduced activity of Kir4.1 channels in hippocampal astrocytes of diabetic $\mathrm{db} / \mathrm{db}$ mice which was associated with deficits in potassium uptake and enhanced CA1 pyramidal cell excitability. These deficits may, in part, explain the predisposition of diabetics to suffer seizures.

\section{Materials and Methods}

\subsection{Animals}

Diabetic homozygous $(\mathrm{db} / \mathrm{db})$ and non-diabetic heterozygous $(\mathrm{db} /+)$ male mice were purchased from Jackson Laboratories (Bar Harbor, ME). Mice were maintained on a 12-h light/dark schedule and had access to food and water ad libitum. All experiments were approved by the Universidad Central del Caribe Institutional Animal Care and Use Committee (IACUC).

\subsection{Blood Glucose Measurement}

Mice were fasted for $5 \mathrm{~h}$ with access only to water. Blood was then obtained from the tail vein and fasting blood glucose levels were measured using a glucose meter and test strips.

\subsection{SDS-PAGE and Western Blotting Analysis}

The hippocampal region was dissected out of brains from control $(\mathrm{db} /+)$ and diabetic $(\mathrm{db} / \mathrm{db})$ mice. The samples were lysed for 60 min with RIPA buffer (Tris HCl 1.5 M pH 8.8, 1\% Triton X-100, $150 \mathrm{mM} \mathrm{NaCl}$ and $0.1 \%$ SDS) with an additional mixture of peptide inhibitors (leupeptin, bestatin, pepstatin, and aprotinin) and 1.0 mM PMSF. Protein concentrations were determined using the Bradford Protein Assay (BioRad) followed by a dilution 1:3 with Urea buffer (4\% SDS, 8 M Urea, 20 mM EDTA, $0.015 \%$ Bromophenol Blue, $5 \% \beta$-mercaptoethanol, $62 \mathrm{mM}$ Tris- $\mathrm{HCl} \mathrm{pH} \mathrm{6.8)} \mathrm{for} \mathrm{a} \mathrm{final} \mathrm{concentration}$ of $10 \mu \mathrm{g}$ protein $/ \mu \mathrm{L}$. Samples were resolved in $4-15 \%$ polyacrylamide gradient gels, transferred 
and immunoblotted using a Guinea pig polyclonal antibody against Kir4.1 (1:2000, Alomone Labs, Jerusalem, Israel), cat\#AGP-035) followed by signal detection with enhanced chemiluminescence methodology (SuperSignal ${ }^{\circledR}$ West Dura Extended Duration Substrate; Pierce, Rockford, IL, USA). Intensity of the signal was measured in a gel documentation system (ChemiDoc, BioRad, Hercules, CA, USA). It has been shown that Kir4.1 can appear in two forms of monomer: unglycosylated and glycosylated which correspond to 37 and $43 \mathrm{kDa}$ bands, respectively [28] and we calculated the total monomer consisting of both the unglycosylated and glycosylated forms. In all cases, intensity of the chemiluminescence signal was corrected for minor differences in protein content after densitometry analysis of the India ink-stained membrane [29].

\subsection{Electrophysiological Recording from Neurons and Astrocytes in Brain Slices}

Hippocampal slices were prepared from adult male $\mathrm{db} / \mathrm{db}$ and $\mathrm{db} /+$ mice (90-110 days postnatal) as previously described [14]. Slices were incubated in oxygenated artificial cerebrospinal fluid (ACSF) containing: $127 \mathrm{mM} \mathrm{NaCl} ; 2.5 \mathrm{mM} \mathrm{KCl} ; 1.25 \mathrm{mM} \mathrm{NaH}_{2} \mathrm{PO}_{4} ; 25 \mathrm{mM} \mathrm{NaHCO}_{3} ; 2 \mathrm{mM} \mathrm{CaCl}_{2} ; 1 \mathrm{mM}$ $\mathrm{MgCl}_{2}$; and $25 \mathrm{mM} \mathrm{D}$-glucose for at least $1 \mathrm{~h}$ before recording. The solution was saturated with $95 \%$ $\mathrm{O}_{2} / 5 \% \mathrm{CO}_{2}$ to achieve $\mathrm{pH} 7.4$.

\subsubsection{Selection and Recording from Astrocytes}

Astrocytes located in the CA1, exclusively in the stratum radiatum area of the hippocampus, were identified by their characteristically small rounded cell bodies and defined irregular processes and were randomly selected (attached, near and far from blood vessels) for electrophysiological recording. Astrocytes were from 50-200 micrometer in depth of the brain slice to avoid recording from damaged cells located on both surfaces of the slices. Only passive astrocytes with a linear I/V-relationship were used for the study [14,30]. By recording from stratum radiatum, we avoided recording from satellite oligodendrocytes [31] and oligodendrocyte precursor cells [32] found in proximity to pyramidal cells. In addition, astrocytes from adult rodents have a linear response to a voltage protocol and are considered "passive glia" [30]. While a small percentage of NG2 cells also have a linear response to a voltage step protocol, the majority of these cells are "variably rectifying glia" [30]. The membrane potentials were not corrected for the theoretical junction potentials between the intracellular and extracellular solutions.

Membrane currents were measured with the single electrode whole-cell patch-clamp technique. Borosilicate glass patch pipettes (O.D. $1.5 \mathrm{~mm}$, I.D. $1.0 \mathrm{~mm}$; World Precision Instruments, Sarasota, FL, USA) were pulled in four-steps using a Sutter P-97 puller (Sutter Instruments, Novato, CA, USA) to a final resistance of 6-9 $\mathrm{M} \Omega$ for astrocyte recordings. The intracellular solution contained: $138 \mathrm{mM}$ $\mathrm{KCl}, 2 \mathrm{mM} \mathrm{KOH}, 1 \mathrm{mM} \mathrm{MgCl}$, $1 \mathrm{mM} \mathrm{CaCl}_{2}, 10 \mathrm{mM}$ EGTA, $10 \mathrm{mM}$ HEPES, $1 \mathrm{mM}$ spermine $\mathrm{HCl}$, $\mathrm{pH}$ adjusted to 7.2 with $\mathrm{KOH} / \mathrm{HCl}$ and had an average osmolarity of $284 \pm 3 \mathrm{mOsm} / \mathrm{L}$. After cell penetration, the access resistance was 10-18 $\mathrm{M} \Omega$, compensated by at least $75 \%$.

The membrane potentials of stratum radiatum astrocytes were determined immediately after attainment of whole-cell mode, and cells were then subsequently held under voltage-clamp at this potential. Astrocytes were bathed with ACSF for $5 \mathrm{~min}$ to allow cell stabilization then a voltage step protocol was applied using $100 \mathrm{~ms}$ voltage steps to potentials between $-100 \mathrm{mV}$ and $+100 \mathrm{mV}$ from the holding potential (equal to the resting membrane potential) to measure the whole-cell currents and I/V-relationship. The patched astrocytes were then superfused with ACSF containing $100 \mu \mathrm{M}$ barium (a selective Kir channel blocker) for $10 \mathrm{~min}$ after which the same voltage step protocol was applied. Barium-sensitive Kir currents were obtained by subtracting the whole-cell current in the presence of barium from the current in the absence of barium.

Using whole-cell voltage-clamp to record from astrocytes in stratum radiatum area of hippocampal slices from $\mathrm{db} / \mathrm{db}$ diabetic and $\mathrm{db} /+$ control mice, we measured inward $\mathrm{K}^{+}$current in response to switching the external solution from one containing $2.5 \mathrm{mM} \mathrm{K} \mathrm{K}^{+}$to one containing $10 \mathrm{mM} \mathrm{K}^{+}$in the presence and absence of $100 \mu \mathrm{M} \mathrm{Ba}^{2+}[14,19]$. Kir-dependent inward currents were obtained by 
subtracting the inward current in the presence of barium from the current in the absence of barium. Only one cell was recorded from each slice that was perfused with barium.

\subsubsection{Recording from Pyramidal Neurons}

Membrane currents were measured with the single electrode whole-cell patch-clamp technique. Borosilicate glass patch pipettes (O.D. $1.5 \mathrm{~mm}$, I.D. 1,0 mm; WPI, Sarasota, FL, USA) were pulled in four steps using a Sutter P-97 puller (Novato, CA, USA) to a final resistance of 2-4 M $\Omega$ for pyramidal cell recordings. The intracellular solution contained: $130 \mathrm{mM}$ K-gluconate, $10 \mathrm{mM}$ Na-gluconate, $4 \mathrm{mM} \mathrm{NaCl}, 4 \mathrm{mM}$ phosphocreatine, $0.3 \mathrm{mM} \mathrm{GTP-Na}, 4 \mathrm{mM}$ Mg-ATP, $10 \mathrm{mM}$ HEPES, and the pH was adjusted to 7.2 with $\mathrm{KOH}$ and the average osmolarity of the intracellular solution was $279 \pm 5 \mathrm{mOsm} / \mathrm{L}$. After cell penetration, the access resistance was 9-12 M $\Omega$, compensated by at least $75 \%$.

The membrane potentials of CA1 pyramidal cells were determined immediately after attainment of whole-cell mode. The membrane potentials were not corrected for the theoretical junction potentials between the intracellular and extracellular solutions, because we used identical conditions for two groups of animals looking just for differences in their properties. We next recorded spontaneous action potential firing for $10 \mathrm{~min}$ followed by recording EPSCs for another $10 \mathrm{~min}$ while perfusing the slice with control ACSF solution. Action potentials were measured in gap-free current equal zero $(I=0)$ mode and EPSCs were measured while holding the cell at $-50 \mathrm{mV}$ in voltage-clamp mode [33]. Following these basal activity measurements, we induced neuronal epileptiform activity using $100 \mu \mathrm{M}$ 4-aminopyridine (4-AP; Sigma) added to the ACSF. We measured EPSCs in the presence of ACSF with $100 \mu \mathrm{M} 4$-AP for $20 \mathrm{~min}$ and $10 \mathrm{~min}$ later (still in the presence of 4-AP) we determined frequency of action potential firing. Only one cell was recorded from each slice that was perfused with 4-AP.

\section{Statistical Methodology}

A normality diagnostic test was performed using the Shapiro-Francia estimator. Presence of outliers was verified via Grubbs test. At a bivariate level, an independent samples $t$-test was used to analyze electrophysiological data obtained from astrocytes and neuronal resting membrane potential. Variance homoscedasticity was evaluated using the Levene protocol, whereas an ordinary one-way ANOVA followed by Tukey's multiple comparison post-hoc test was used to analyze neuronal small EPSCs. Neuronal action potential event frequency and small and large EPSC event frequency were analyzed within the same group model. This model constitutes the comparison of mice as separate units of analysis. In each case, we analyzed control (non-diabetic) groups against experimental groups in $\mathrm{db} / \mathrm{db}$ mice stratified by four analytical blocks as follows: control-control; control-experimental; experimental-control and experimental-experimental., This model was analyzed with a Jonckheere-Terpstra $k$ independent groups test with a modified Bonferroni post-hoc correction or a Mann-Whitney two independent groups test.

To evaluate the time effect in small EPSCs, a modified General Linear Model Repeated Measures ANOVA was used. A Mauchly's test of sphericity was performed to assess if our model has the assumption of compound symmetry. If non-significant $(p \leq 0.05)$ we report the univariate results with a Greenhouse-Geisser epsilon correction; if significant $(p<0.05)$, we report the multivariate results using the Pillai's trace estimator. Either of the last explained results was used to evaluate the time effect in our models.

The estimated marginal means with their correspondent standard errors are reported for each factor in the experiments. The significant level $(\alpha)$ was set to $\leq 0.05$, excluding the normality and homocedasticity tests $(p>0.05)$. The IBM Statistical Package for Social Sciences v.23.0 for Windows was used (IBM-SPSS, Chicago, IL, USA).

\section{Results}

We have previously shown that normal astrocytes cultured in hyperglycemic conditions switched their behavior and have impaired function of Kir4.1 channels and decreased capability to buffer 
extracellular glutamate [26]. We now extended these findings to examine if Kir4.1 channel protein expression is decreased in hippocampus of diabetic $\mathrm{db} / \mathrm{db}$ male mice $(n=3)$ as compared with non-diabetic $\mathrm{db} /+$ controls $(n=3)$. The average fasting blood glucose levels were $138 \pm 23 \mathrm{mg} / \mathrm{dL}$ (mean $\pm \mathrm{SEM} ; n=3$ ) for control mice and $547 \pm 30 \mathrm{mg} / \mathrm{dL}$ for diabetic mice. In the case of one $\mathrm{db} / \mathrm{db}$ mouse the blood glucose level was higher than the sensitivity of the meter and we used the upper detectable level of $600 \mathrm{mg} / \mathrm{dL}$ for this mouse. Using Western blot analysis (Figure 1), we obtained a $43 \mathrm{kDa}$ band corresponding to glycosylated Kir4.1 monomer and a $37 \mathrm{kDa}$ band corresponding to the unglycosylated Kir4.1 monomer as previously described [28]. Using both bands for calculating Kir4.1 monomer levels in control and diabetic mice, we found that protein levels were $31 \%$ lower in the hippocampal region of $\mathrm{db} / \mathrm{db}$ diabetic mice as compared with $\mathrm{db} /+$ (Figure 1 ). Kir4.1 is found primarily in glial cells in brain [11,33], therefore, these data reflect a reduction in Kir4.1 channels in glia, not neurons.

A

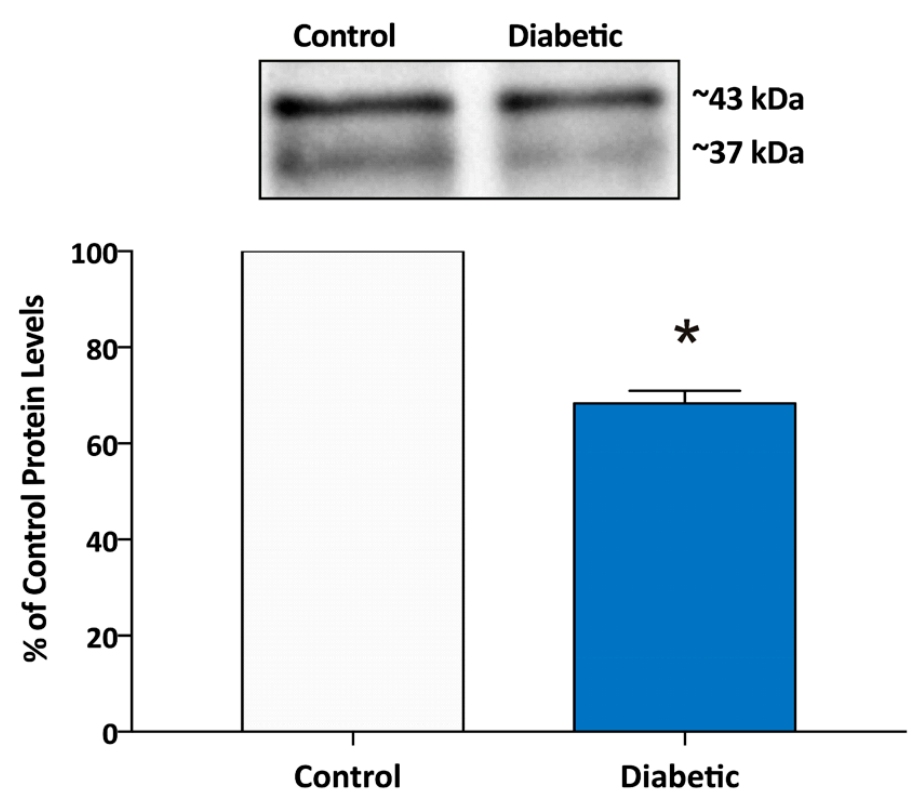

B

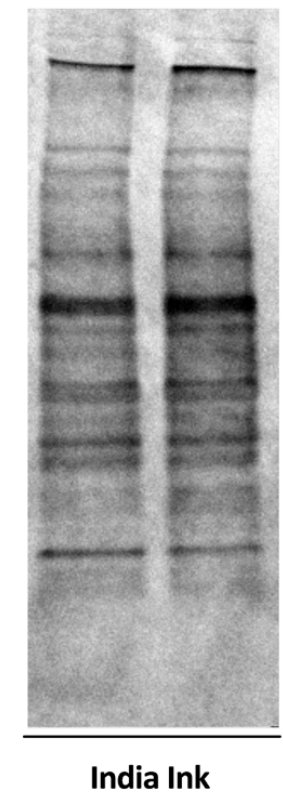

Figure 1. Kir4.1 potassium channel protein levels are lower in the hippocampal region of brains from diabetic mice as compared with non-diabetic control mice. (A) Kir4.1 potassium channel protein levels (total monomer of both glycosylated and unglycosylated forms of Kir4.1) measured by Western Blot in hippocampus from diabetic mice were significantly downregulated $(68.3 \pm 2.6 \%, n=3)$ as compared to control. Data are expressed as \% of control with control being hippocampus from non-diabetic mice and * indicating a significant difference from control group $(p<0.05$; Student's $t$-Test for independent samples). Above the graph in (A) are representative bands from the Western blot showing Kir4.1 protein levels from a control and a diabetic mouse. The band detected at $\sim 37 \mathrm{kDa}$ corresponds to the unglycosylated form, whereas the band detected at $\sim 43$ corresponds to the glycosylated form of the Kir4.1 monomer. (B) The India ink-stained membrane showing the total protein of the samples shown in (A) that was used for loading control calculations.

Furthermore, we examined if Kir4.1 channel electrophysiological properties are impaired in diabetic $\mathrm{db} / \mathrm{db}$ male mice as compared with non-diabetic $\mathrm{db} /+$ controls. The fasting blood glucose levels for $\mathrm{db} /+$ control mice ranged between $123 \mathrm{mg} / \mathrm{dL}$ and $143 \mathrm{mg} / \mathrm{dL}$, whereas the levels for $\mathrm{db} / \mathrm{db}$ diabetic mice were in the range of $425 \mathrm{mg} / \mathrm{dL}$ to $513 \mathrm{mg} / \mathrm{dL}$.

Since the highly hyperpolarized membrane potential of astrocytes is largely due to the expression of Kir4.1 channels, we measured the membrane potential of astrocytes in CA1 hippocampal brain slices obtained from diabetic $\mathrm{db} / \mathrm{db}$ and non-diabetic $\mathrm{db} /+$ mice. Astrocytes from $\mathrm{db} / \mathrm{db}$ mice were depolarized $(-78.0 \pm 1.3 \mathrm{mV} ; n=53$ from 7 mice $)$ when compared to their $\mathrm{db} /+$ counterparts $(-85.7 \pm 0.5 \mathrm{mV} ; n=51$ 
from 9 mice) (Figure 2A). Some of the membrane potentials of astrocytes from db/db mice were highly hyperpolarized as for those of $\mathrm{db} /+$ astrocytes, but a population of the cells in $\mathrm{db} / \mathrm{db}$ mice were more depolarized. The difference was reflected in the median membrane potentials for astrocytes from diabetic and control mice which were $-80 \mathrm{mV}$ and $-86 \mathrm{mV}$, respectively and can be clearly seen in the scatterplot (Figure 2A).

A

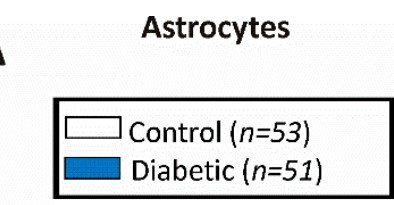

B

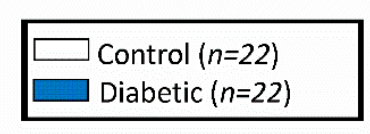

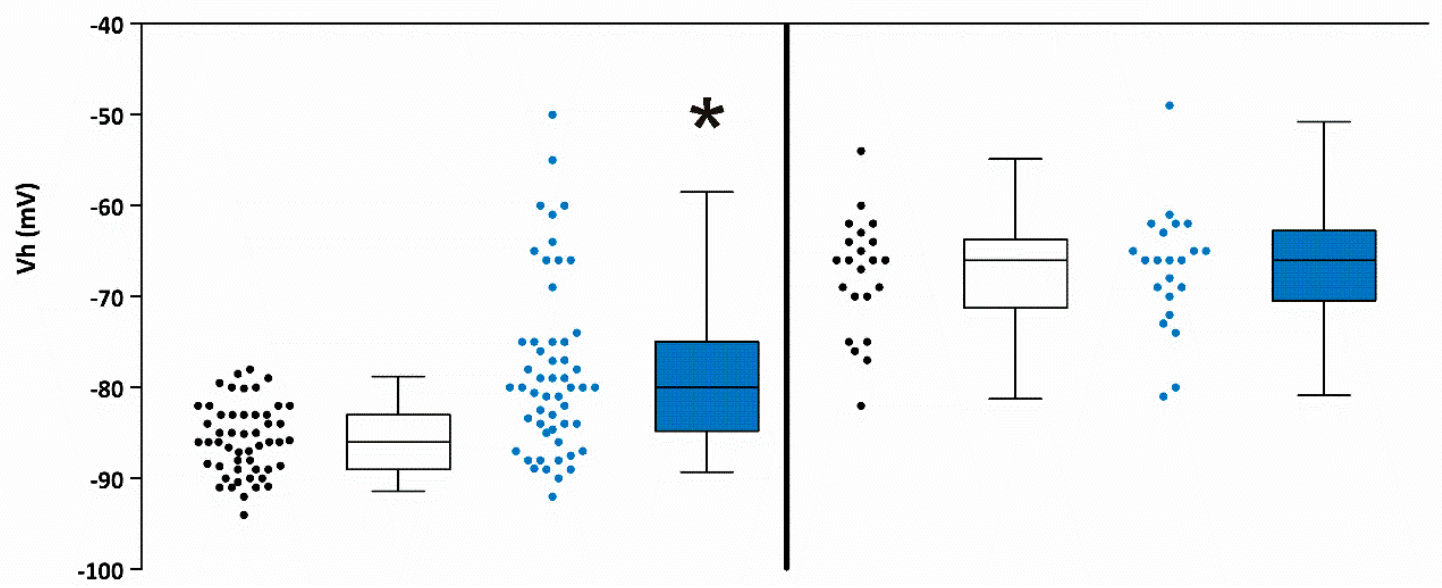

Figure 2. Membrane potentials of astrocytes and neurons in CA1 hippocampal slices from control and diabetic mice. (A) Average membrane potential of astrocytes from hippocampal CA1 stratum radiatum area of brain slices from control $(-85.7 \pm 0.6 \mathrm{mV}$; mean $\pm \mathrm{SEM} ; n=51$ from 9 mice $)$ and diabetic $(-78.0 \pm 1.3 \mathrm{mV} ; n=51$ from 7 mice $)$ mice. Asterisk * indicates significant difference from the control group ( $p<0.05$; Student's $t$-Test for independent samples). (B) Average membrane potential of pyramidal neurons from hippocampal CA1 stratum radiatum area from control $(-67 \pm 1.4 \mathrm{mV} ; n=22$ from 8 mice) and diabetic ( $-67 \pm 1.5 \mathrm{mV} ; n=22$ from 5 mice) mice.

To determine the contribution of Kir channels to the total whole cell currents of CA1 hippocampal astrocytes, brain slices were first perfused with a standard ACSF solution and astrocytes were clamped and held at their native resting membrane potential $(\mathrm{Vm})$, so that $\mathrm{Vm}=\mathrm{Vh}$. Under these conditions, application of $100 \mathrm{~ms}$ voltage steps to potentials between $-100 \mathrm{mV}$ and $+100 \mathrm{mV}$ from the holding potential (equal to the resting membrane potential) evoked both inward and outward currents that were substantially larger in $\mathrm{db} /+$ astrocytes than those elicited in $\mathrm{db} / \mathrm{db}$ astrocytes (Figure 3A1). Upon application of the Kir channel blocker, $\mathrm{Ba}^{2+}(100 \mu \mathrm{M})$, currents in astrocytes from db/+ mice were inhibited by about $50 \%$ (Figure $3 \mathrm{~A} 2$ open squares), but there was significantly less effect of $\mathrm{Ba}^{2+}$ on the current-voltage curve of $\mathrm{db} / \mathrm{db}$ astrocytes (Figure 3A2, filled blue squares,) as summarized in Figure 3C. To obtain the $\mathrm{Ba}^{2+}$ sensitive currents which reflect the current contributed by functional Kir channel expression (Figure 3A3), we subtracted the current in the presence of $\mathrm{Ba}^{2+}$ (Figure 3A2) from the total whole currents (Figure 3A1). The average inward whole cell currents measured at $-150 \mathrm{mV}$ in ACSF are shown in Figure 3B. $\mathrm{Ba}^{2+}$ sensitive inward currents (measured at $-150 \mathrm{mV}$ ) from diabetic mice astrocytes ( $-0.4 \mathrm{nA} ; n=21$ cells from 7 mice) were substantially smaller than those obtained from non-diabetic animals ( $-1.8 \mathrm{nA} ; n=11$ cells from 9 mice) and are summarized as percent of current blocked by barium in Figure 3C. Taken together, the depolarized membrane potential, the smaller current elicited from $\mathrm{db} / \mathrm{db}$ astrocytes and the decreased response to $\mathrm{Ba}^{2+}$ application indicate that functional (membrane) Kir channel activity is substantially reduced in astrocytes of $\mathrm{db} / \mathrm{db}$ mice as compared with $\mathrm{db} /+$ astrocytes. 
A1

Whole cell currents

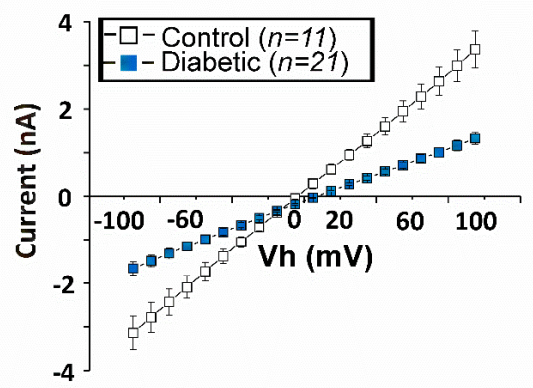

A2

Whole cell currents with Barium

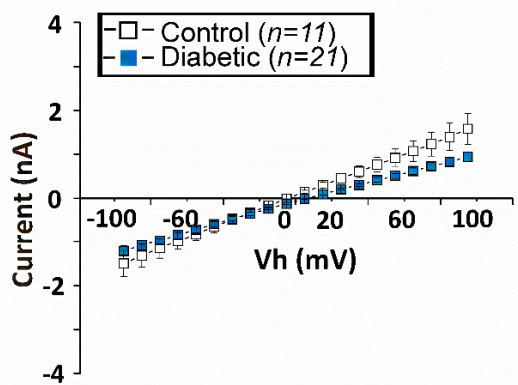

A3

Barium sensitive currents

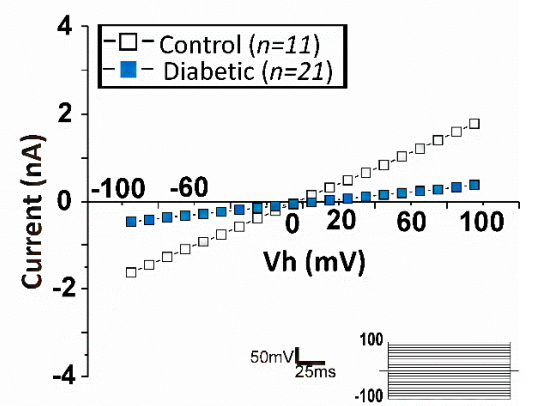

B

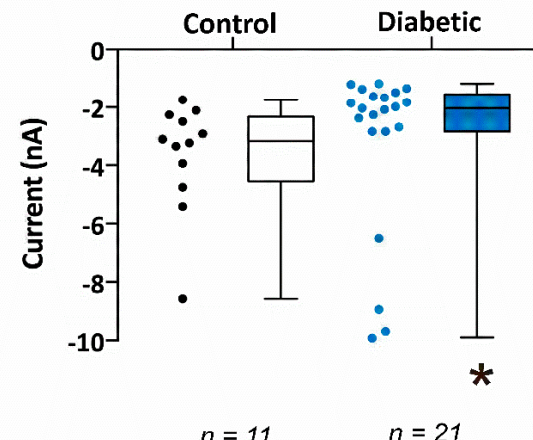

C

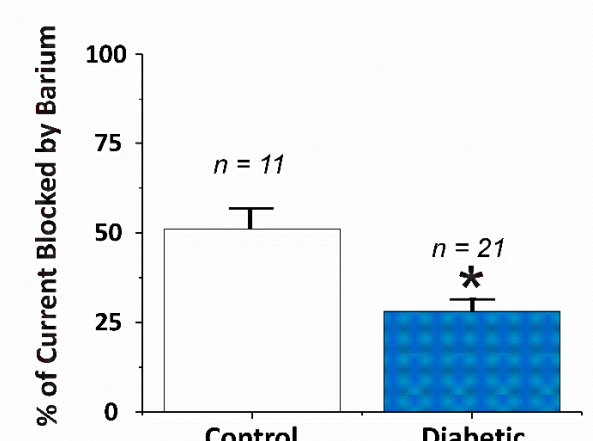

Figure 3. Kir currents are reduced in CA1 hippocampal astrocytes from diabetic mice. Astrocytes were clamped at holding potential (Vh) which was equal to the resting membrane potential $(\mathrm{Vm})$ in $2.5 \mathrm{mM}\left[\mathrm{K}^{+}\right]_{\mathrm{o}}$ containing artificial cerebrospinal fluid $(\mathrm{ACSF}), \mathrm{Vh}=\mathrm{Vm}$. I/V-curves are shown in response to a voltage step protocol (100 ms voltage steps to potentials between $-100 \mathrm{mV}$ and $+100 \mathrm{mV}$ from the holding potential (Vh)). (A1) Whole cell currents recorded in response to a voltage step protocol from astrocytes in hippocampal brain slices obtained from control (open squares) or diabetic (filled blue squares) mice. (A2) Whole-cell currents recorded in response to a voltage step protocol in the presence of $100 \mu \mathrm{M} \mathrm{Ba}^{2+}$ (a blocker of Kir channels) from astrocytes in hippocampal brain slices obtained from control or diabetic mice. (A3) $\mathrm{Ba}^{2+}$ sensitive Kir currents from astrocytes from control or diabetic mice. The graph shows the subtraction of currents obtained in the presence of $\mathrm{Ba}^{2+}$ (A2) from total whole-cell currents shown in (A1). $\mathrm{Ba}^{2+}$-sensitive currents reflect the contribution of Kir channels to the whole cell currents. (B) Inward current measured at $-150 \mathrm{mV}$ in astrocytes from control and diabetic mice. (C) Percentage of current blocked by $100 \mu \mathrm{M} B \mathrm{a}^{2+}$ in astrocytes from control and diabetic mice. Data were obtained from $9 \mathrm{db} /+$ control and $7 \mathrm{db} / \mathrm{db}$ diabetic mice. Data in $(\mathbf{B}, \mathbf{C})$ are displayed as mean \pm SEM. Asterisk $\left({ }^{*}\right)$ indicates significant difference from the non-diabetic control group ( $p<0.05$; Student's $t$-Test for independent samples). 
One of the major functions of astrocytes is the removal of excess potassium from active synaptic areas $[11,18]$. Kir4.1 channels in astrocytes contribute to potassium uptake, therefore, we tested the potassium uptake capabilities of astrocytes via Kir channels using a physiologically relevant protocol $[12,14,19,26]$. We clamped each astrocyte to their native resting membrane potential, thus zero current, while perfusing the slice with control ACSF containing $2.5 \mathrm{mM} \mathrm{K}^{+}$. We then measured inward $\mathrm{K}^{+}$current in response to switching the external solution from one containing $2.5 \mathrm{mM} \mathrm{K}^{+}$to one containing $10 \mathrm{mM} \mathrm{K}^{+}$(Figure $4 \mathrm{~A}$ ). This was done in the presence and absence of $100 \mu \mathrm{M} \mathrm{Ba}^{2+}$. Average inward currents generated by switching extracellular $\mathrm{K}^{+}$from 2.5 to $10 \mathrm{mM}$ were significantly smaller in astrocytes from diabetic mice ( $-403 \pm-102 \mathrm{pA} ; n=12$ cells from 6 mice) compared to astrocytes from non-diabetic mice ( $-668 \pm-101 \mathrm{pA} ; n=15$ cells from 6 mice). In addition, we found that there was significantly less $\mathrm{Ba}^{2+}$ sensitive Kir current recorded in astrocytes from diabetic mice $(26 \pm 3 \% ; n=15$ cells from 6 mice) compared with non-diabetic mice ( $39 \pm 5 \% ; n=12$ cells from 6 mice; Figure 4B).

A

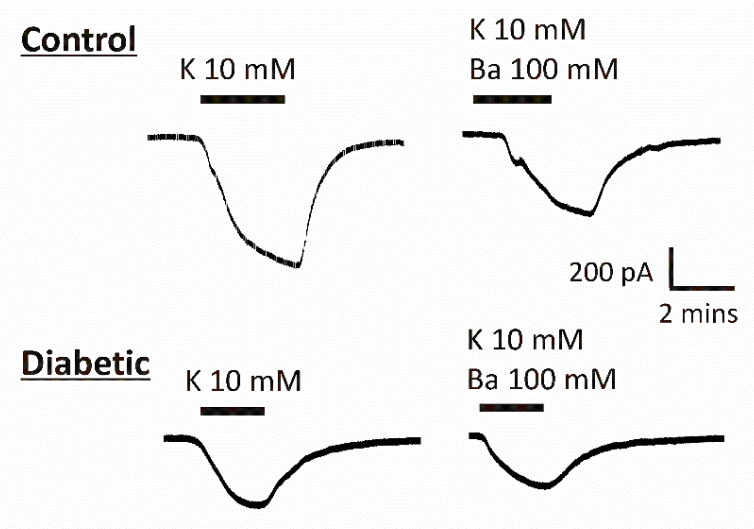

B

$$
n=15 \quad n=12
$$

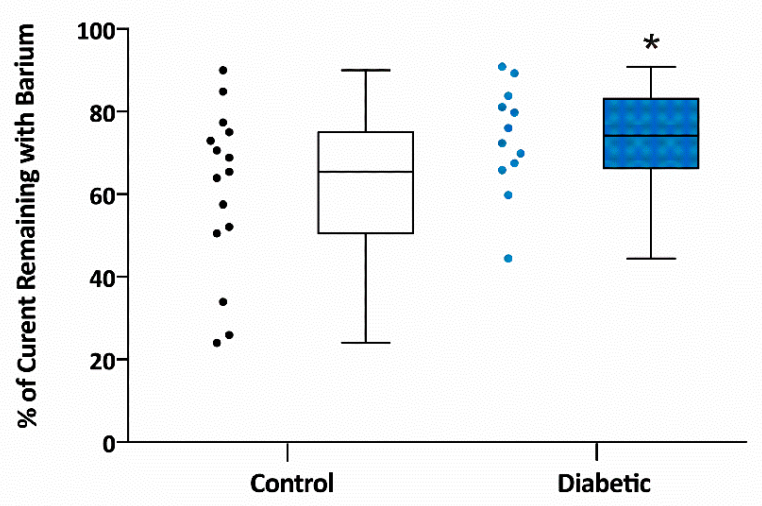

Figure 4. Potassium uptake is impaired in CA1 hippocampal astrocytes from diabetic mice. (A) Representative whole cell currents recorded from astrocytes of control and diabetic mice in hippocampal brain slices. Inward currents were obtained by changing extracellular $\mathrm{K}^{+}$from $2.5 \mathrm{mM}$ to $10 \mathrm{mM}$ in the presence or absence of $100 \mu \mathrm{M} \mathrm{Ba}^{2+}$. The cells were held at the steady state potential $(\mathrm{Vh}=\mathrm{Vm})$. The scales bars are equal for all current traces. (B) Summary of the relative barium insensitive Kir currents measured in hippocampal astrocytes from control $(n=15)$ and diabetic $(n=12)$ mouse brain slices. In (B), the data are expressed as percent (\%) of control current that is barium sensitive where $100 \%$ is the maximal current measured by switching extracellular $\left[\mathrm{K}^{+}\right]$from 2.5 to $10 \mathrm{mM}$. Data were obtained from $6 \mathrm{db} /+$ control and $6 \mathrm{db} / \mathrm{db}$ diabetic mice. Asterisk $\left(^{*}\right)$ indicates significant difference from the non-diabetic control group ( $p<0.05$; Student's $t$-Test for independent samples). 
Electrophysiological properties of hippocampal CA1 pyramidal neurons were measured in brain slices from diabetic and non-diabetic mice. We first measured the resting membrane potential of pyramidal cells in the CA1 area of the hippocampus. As shown in Figure 2B, the resting membrane potentials of CA1 pyramidal cells of non-diabetics $(-67 \pm 1.5 \mathrm{mV} ; n=22$ cells from 8 mice) and diabetics $(-67 \pm 1.4 \mathrm{mV} ; n=22$ cells from 5 mice $)$ were not different.

Spontaneous action potential activity was determined for both diabetic and non-diabetic mice (Figure 5). Interestingly, 77\% of CA1 pyramidal cells recorded from diabetic mice and only $39 \%$ of the CA1 pyramidal cells from non-diabetic mice displayed spontaneous action potential firing in brain slices (Figure 5A). Similar results were seen after application of the pro-convulsant 4-aminopyridine (4-AP; $100 \mu \mathrm{M})$. Thirty minutes after application of $4-\mathrm{AP}, 69 \%$ of the CA1 cells from diabetic animals and $42 \%$ of the recorded cells from non-diabetic mice were spontaneously active (Figure 5A).

We next measured the action potential frequency (averaged over $10 \mathrm{~min}$ ) before and after application of 4-AP. Action potential frequency was $\approx 9$ times higher in diabetic $(0.26 \pm 0.12 \mathrm{~Hz} ; n=13$ cells from 5 mice) compared with non-diabetic mice $(0.03 \pm 0.01 \mathrm{~Hz} ; n=11$ cells from 8 mice) prior to application of 4-AP (Figure 5B). Furthermore, 30 min after perfusion with $100 \mu \mathrm{M} 4-\mathrm{AP}$, the average action potential frequency increased for CA1 pyramidal cells recorded from slices obtained from both diabetic $(0.69 \pm 0.36 \mathrm{~Hz} ; n=11$ cells from 5 mice $)$ and non-diabetic mice $(0.15 \pm 0.07 \mathrm{~Hz} ; n=11$ cells from 8 mice). In addition, the firing frequency was significantly greater ( $\approx 5$ times) for CA1 neurons from diabetic mice compared with control mice (Figure 5B).

Excitatory post-synaptic currents (EPSC) were recorded from CA1 pyramidal cells in the presence and absence of 4-AP $(100 \mu \mathrm{M})$, while holding the cells at $-50 \mathrm{mV}$. EPSCs were classified as small or large based on the amplitude of the recorded inward current. Small EPSCs were $20 \mathrm{pA}$ or smaller whereas currents greater than $20 \mathrm{pA}$ were categorized as large EPSCs. The small EPSCs were counted manually for one minute every 5 min of recording, whereas the large EPSCs were calculated using the event detection and threshold search feature of clampfit (Axon Instruments) set as $21 \mathrm{pA}$. Figure 6A (control) and 5B (diabetic) show the percent of cells displaying any small or large EPSCs before or after application of 4-AP. Less than $20 \%$ of the cells from non-diabetic mice displayed small EPSCs in ACSF whereas over $40 \%$ of the cells recorded from diabetic mice showed small EPSCs while superfused with ACSF. As expected, the number of cells displaying EPSCs increased after application of 4-AP in slices from both non-diabetic and diabetic mice (Figure 6A,B). 


\section{A Spontaneous Activity}

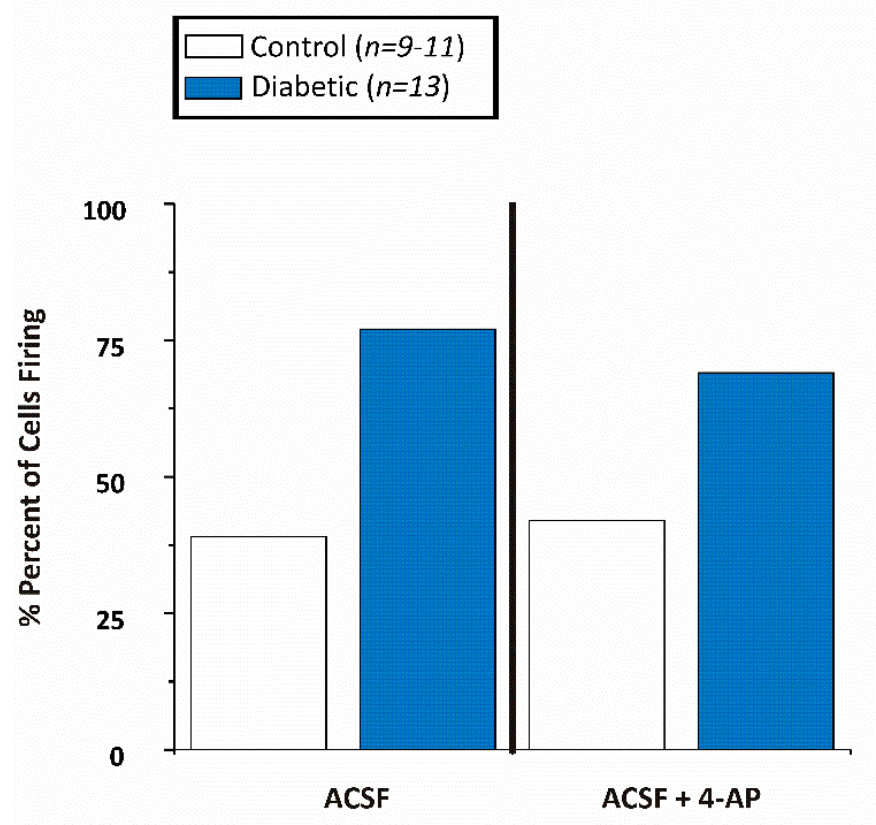

B Action Potential Frequency

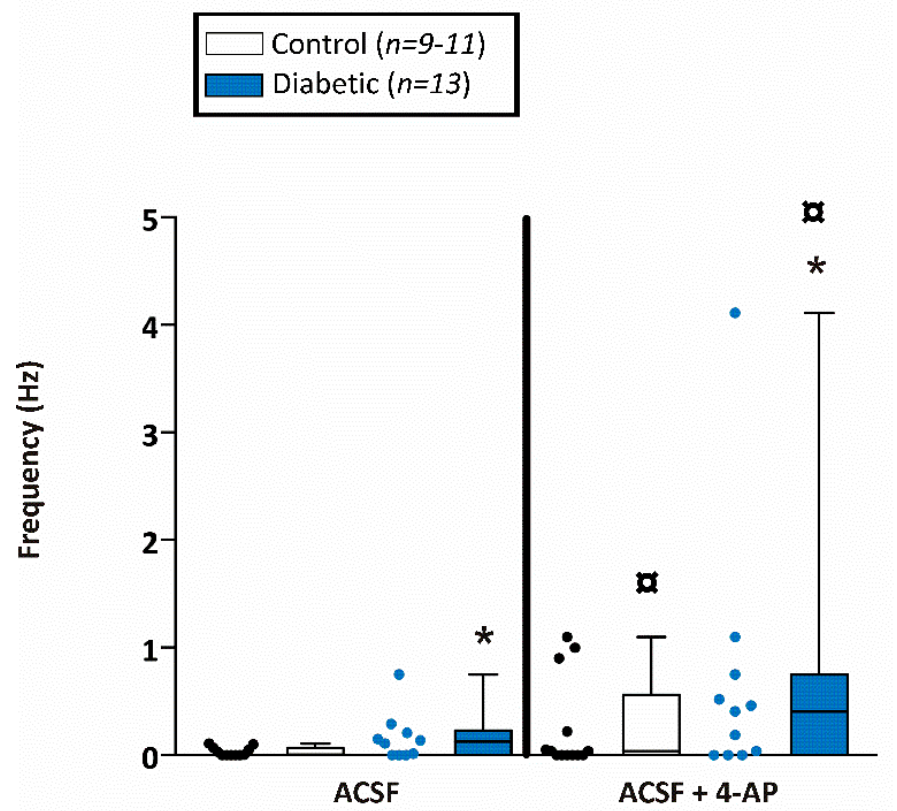

Figure 5. CA1 pyramidal neurons from diabetic mice were hyperexcitable. (A) Percent of CA1 pyramidal neurons firing any action potentials within the $10 \mathrm{~min}$ recording period while being perfused with either ACSF or ACSF containing $100 \mu \mathrm{M}$ 4-aminopyridine (4-AP). (B) Action potential firing frequency $(\mathrm{Hz})$ of CA1 pyramidal neurons during the $10 \mathrm{~min}$ recording period while being perfused with either ACSF or ACSF containing $100 \mu \mathrm{M}$ 4-AP. Data were obtained from 9-11 cells of $8 \mathrm{db} /+$ control and 13 cells from $5 \mathrm{db} / \mathrm{db}$ diabetic mice. Asterisk $\left.{ }^{*}\right)$ indicates significant difference from the corresponding non-diabetic control whereas the boxed circle $(\mathbb{\alpha})$ indicates significant difference after application of 4-AP from the same non-diabetic or diabetic ACSF group $(p<0.05$; Jonckheere-Terpstra $k$ independent groups test). 
A

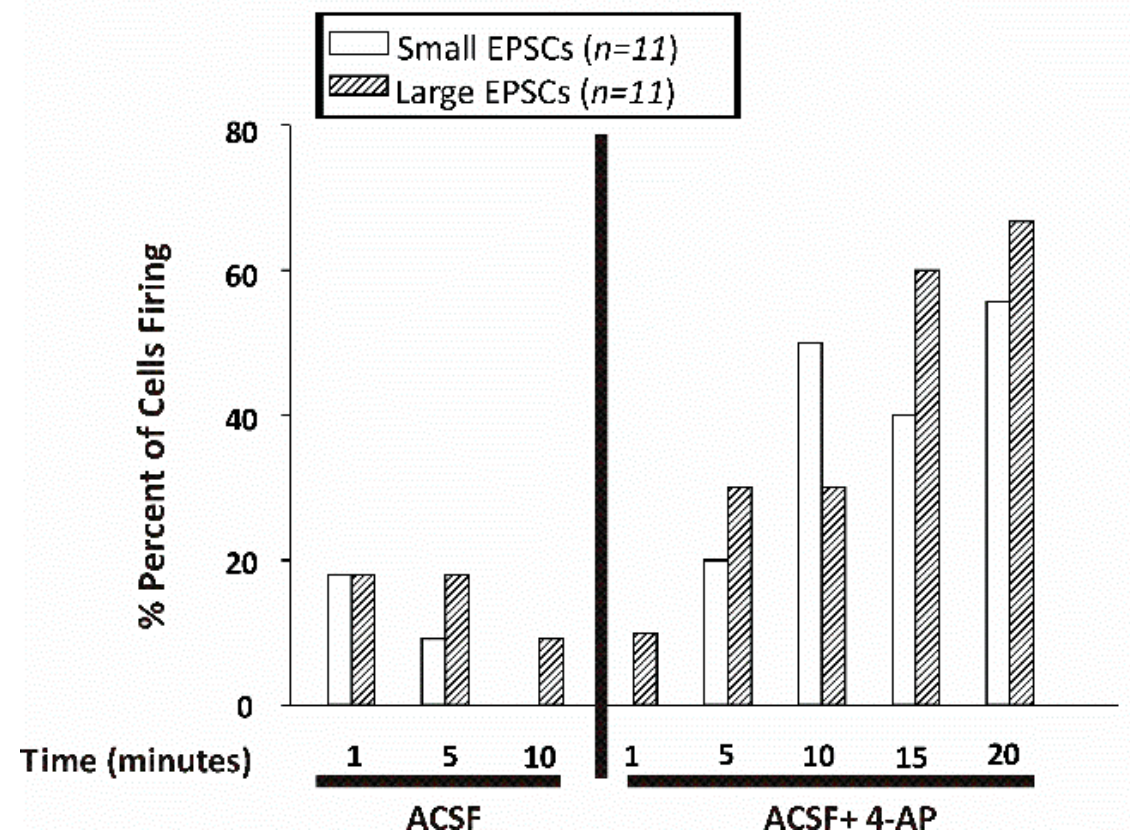

B

Diabetic Mice

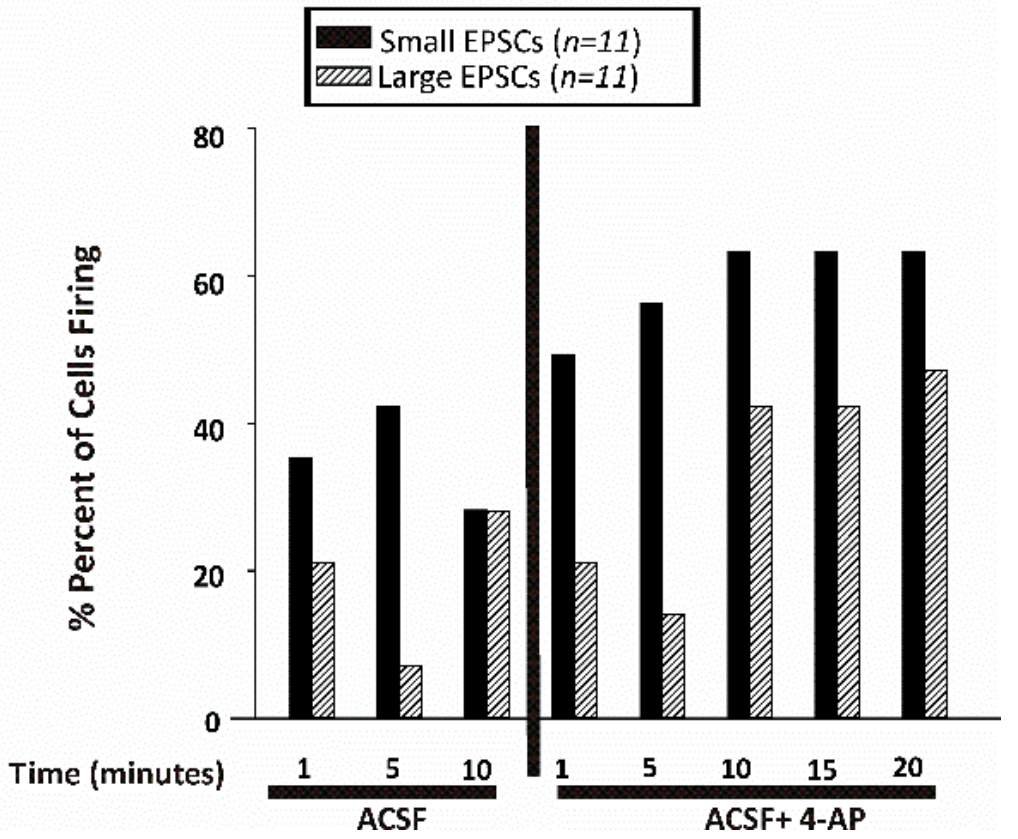

Figure 6. CA1 pyramidal neurons from diabetic mice displayed more small excitatory post-synaptic currents. Percent of cells displaying small EPSCs ( $\leq 20 \mathrm{pA})$ or large EPSCs $(>20 \mathrm{pA})$ recorded for one minute every 5 min of recording in CA1 pyramidal neurons from control (A) or diabetic (B) mice. Data were obtained from 11 cells from $8 \mathrm{db} /+$ control and 12 cells from $5 \mathrm{db} / \mathrm{db}$ diabetic mice. 
We then determined frequency of small EPSCs in one minute intervals every 5 min (Figure 7A). Interestingly, we found that the frequency of EPSCs was significantly higher in CA1 neurons from diabetic mice throughout the entire recording period (i.e., both before and after 4-AP) and this difference was enhanced after the application of 4-AP (Figure 7A). Indeed, after application of $100 \mu \mathrm{M} 4$-AP, the small EPSC frequency was significantly increased only in CA1 pyramidal cells in slices from diabetic mice, but not for non-diabetic mice. This provides further indication that neurons from diabetic mice are hyperexcitable compared to control.

A

Small EPSC

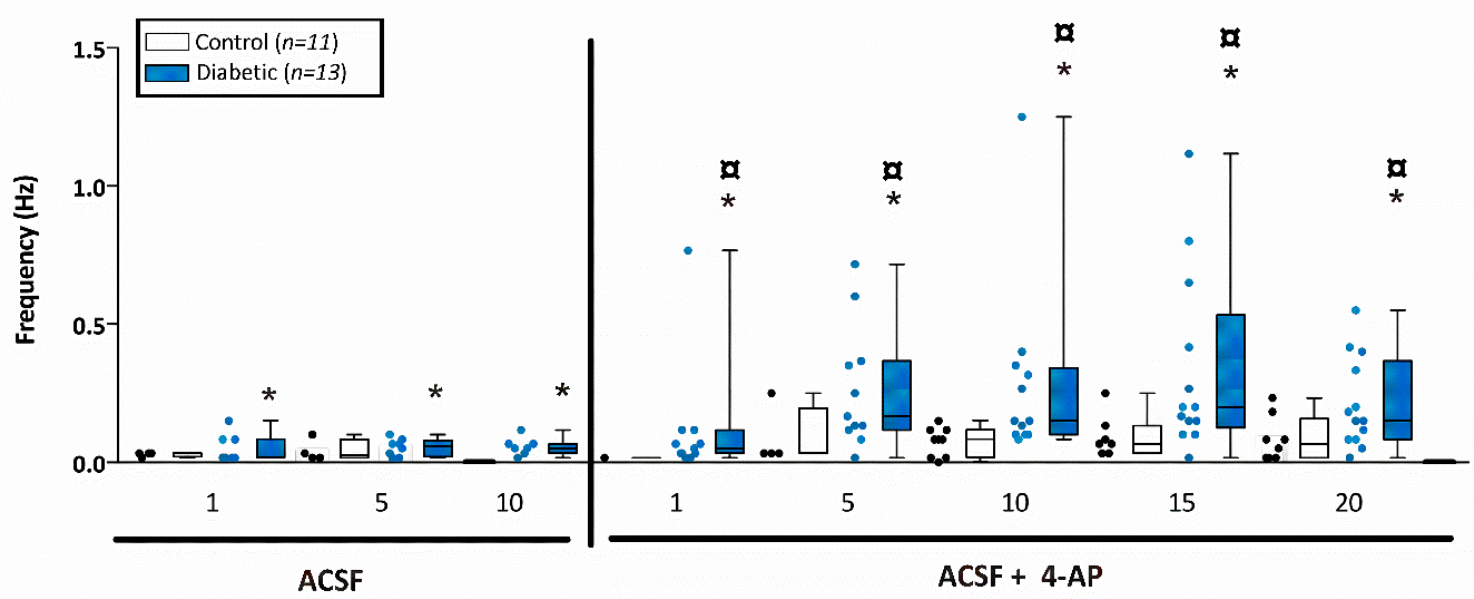

B

Large EPSC

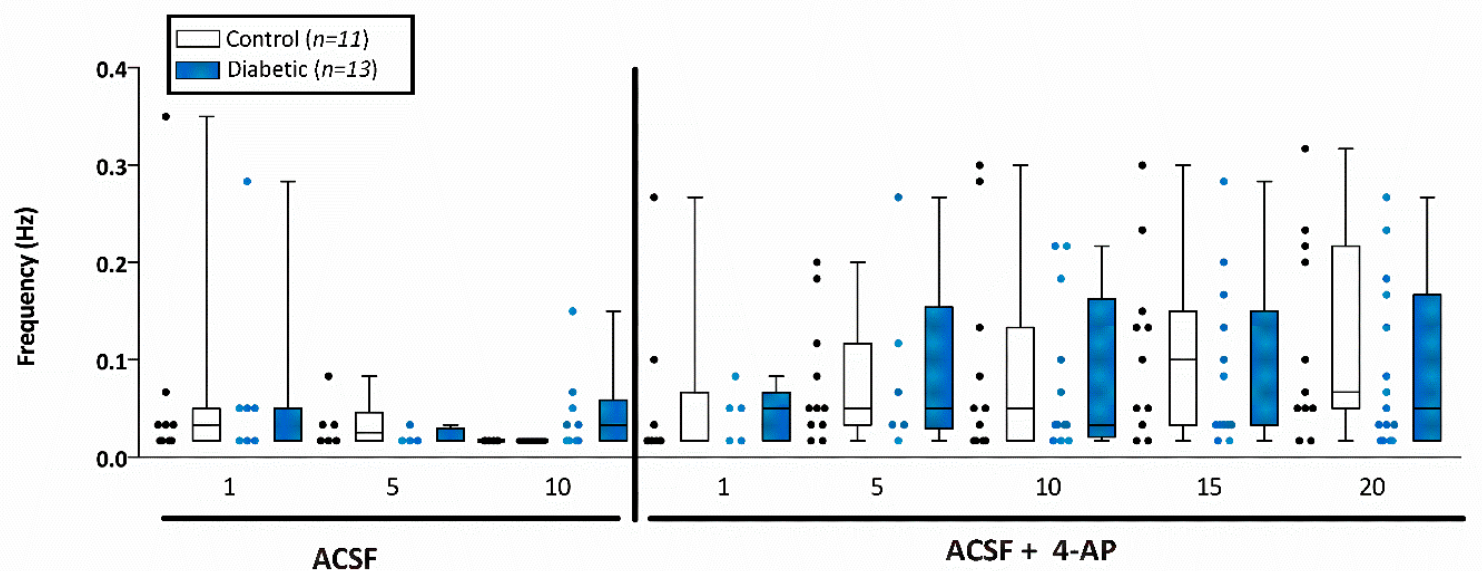

Figure 7. CA1 pyramidal neurons from diabetic mice displayed more excitatory post-synaptic currents. Excitatory post-synaptic currents (EPSC) event frequency of small EPSCs ( $\leq 20 \mathrm{pA})$ or large EPSCs $(>20 \mathrm{pA})$ recorded for one minute every $5 \mathrm{~min}$ of recording in CA1 pyramidal neurons from control or diabetic mice. (A) Small EPSC frequency $(\mathrm{Hz})$ recorded in CA1 pyramidal neurons from control (open bars) or diabetic (filled blue bars) mice before and after application of 4-AP. Asterisk ${ }^{*}$ ) indicates significant difference from the corresponding non-diabetic control whereas boxed circle $(\not \alpha)$ indicates significant difference after application of 4-AP from the same non-diabetic or diabetic ACSF group ( $p<0.05$; Jonckheere-Terpstra k independent groups test). (B) Large EPSC frequency (Hz) recorded in CA1 pyramidal neurons from control (open bars) or diabetic (filled blue bars) mice. Data were obtained from 11 cells from $8 \mathrm{db} /+$ control and 12 cells from $5 \mathrm{db} / \mathrm{db}$ diabetic mice. The large EPSCs recorded from CA1 pyramidal neurons were significantly greater after 4-AP in both control and diabetic mice although there was no difference in the frequency between control and diabetic mice at any time point examined either before or after 4-AP. 
Finally, we measured large EPSC frequency in one minute intervals every $5 \mathrm{~min}$ for $10 \mathrm{~min}$ before application of 4-AP and for $20 \mathrm{~min}$ after application of 4-AP (Figure 7B). There was no significant difference in the large EPSC frequency observed in CA1 neurons between diabetic ( $n=12$ cells from 5 mice) and non-diabetic mice ( $n=11$ cells from 8 mice) prior or after application of 4-AP. Large EPSCs have been reported to be the summation of synchronized inputs onto the cell and they become particularly apparent after 4-AP. After 4-AP, the frequency of large EPSCs was significantly increased in both diabetic and non-diabetic mice.

\section{Discussion}

While the association between seizures and diabetes is widely accepted in the medical community, the pathophysiology has yet to be elucidated $[25,34,35]$. It has been shown that long-term treatment with streptozotocin to induce hyperglycemia/diabetes increases epileptiform like activity in pyramidal neurons in the CA3 area of the hippocampus [36]. Moreover, streptozotocin treated rats display increased seizure severity and death related to status epilepticus induced by pilocarpine [37]. In addition, these rats show markedly increased neuronal loss and reduced long-term potentiation in the CA3 area of the hippocampus [37]. Consistent with these findings, systemic administration of glucose in rats (hyperglycemic condition) decreased seizure threshold in the flurothyl seizure test [38].

To date, there are no reports about spontaneous seizure activity in $\mathrm{db} / \mathrm{db}$ mice. Therefore, in the present study, we used a db/db mouse model of type 2 diabetes [27] and evaluated neuronal excitability in both basal conditions and after application of 4-AP. We compared the electrophysiological properties of CA1 hippocampal neurons in brain slices obtained from non-diabetic $\mathrm{db} /+$ mice and diabetic $\mathrm{db} / \mathrm{db}$ mice. Although there was no difference in the mean resting membrane potential of CA1 pyramidal cells from non-diabetic and diabetic mice, neurons recorded from diabetic mice were hyperexcitable. This was evident in both spontaneous action potential firing as well as the frequency of small EPSCs with both being higher in diabetic mice.

There are a number of intrinsic mechanisms reported that have been shown to contribute to increased neuronal excitability such as: (i) increased number and distribution of ion channels [39], (ii) activation of second-messenger systems that affect channel function [40] and (iii) modulation of gene expression of ion channels [41]. However, there are also a number of extrinsic mechanisms that could influence neuronal excitability such as: (i) changes in extracellular ion concentration [42], (ii) remodeling of synaptic contacts [43] and (iii) modulation of transmitter metabolism or uptake by glial cells [44]. The present study focuses on the potential influence of extrinsic mechanisms to alter neuronal excitability.

The $\mathrm{db} / \mathrm{db}$ mice are hyperglycemic. Among the effects of hyperglycemia seen on neurons in streptozotocin-induced diabetic rats are increased $\alpha$-amino-3-hydroxy-5-methyl-4-isoxazolepropionic acid (AMPA) and NMDA receptor channel density $[45,46]$. However, type 2 diabetic $\mathrm{db} / \mathrm{db}$ mice also have increased plasma insulin levels and it has been reported that insulin, by itself, could positively potentiate current through NMDA receptors and increase neuronal electrical coupling [46].

Furthermore, among the effects of hyperglycemia seen in glial cells, It has been shown that GFAP immunoreactivity increases in the hippocampus of streptozotocin treated mice [47]. In addition, there is an increase in the numbers of $\mathrm{GFAP}^{+}$Müller cells in the retina of $\mathrm{db} / \mathrm{db}$ mice as compared with non-diabetic controls [48]. Additionally, it is known that hyperglycemia reduces Kir4.1 potassium channel expression and activity in cultured cortical astrocytes [26] and in retinal Müller glial cells [49]. Downregulation of Kir4.1 potassium channels in astrocytes may provide a compelling mechanism to account for the propensity of diabetics to have seizures. Key features of astrocytes that make them well suited to maintain ionic and neurotransmitter homeostasis are their large $\mathrm{K}^{+}$permeability and their highly hyperpolarized native membrane potential.

One of the main contributors of a hyperpolarized membrane potential is the functional expression of Kir4.1 channels in astrocytic membranes. The strict dependence of the Kir4.1 channels on voltage and extracellular $\mathrm{K}^{+}$variations allows $\mathrm{K}^{+}$influx at hyperpolarized resting membrane potential 
and also efflux when $\left[\mathrm{K}^{+}\right]_{\mathrm{o}}$ is low $[11,50]$. Natively, they can be found as homomeric channels or as heteromeric channels together with Kir5.1 subunits. However, in the hippocampus, the Kir4.1 homomer predominates $[17,28]$.

Although Kir4.1 channels are the major channels in astrocytes which contribute to resting membrane potential and $\mathrm{K}^{+}$uptake $[12,13,17]$, there are other $\mathrm{K}^{+}$channels that may contribute to these processes in astrocytes and other glial cells. Seifert et al., (2009) showed that hippocampal astrocytes express not only Kir4.1 channels, but also express other Kir channel subunits from the Kir2.0 family [17] although only the Kir4.1 transcript was invariably found in all the astrocytes tested. Thomzig et al., (2001) reported that hippocampal astrocytes also express the Kir6.1 pore-forming subunit [51], but these Kir6.1 containing channels only function when cells are metabolically challenged and ATP concentrations are reduced. In addition to Kir channels, astrocytes have been reported to express tandem pore domain $\mathrm{K}^{+}$channels including TREK-1, TREK-2, and TWIK-1 [17,52,53] as well as TASK-1 and TASK-3 [52]. Some of these channels may contribute to the barium-insensitive component of the resting membrane potential and $\mathrm{K}^{+}$uptake by astrocytes.

In addition, it has been shown that downregulation of Kir4.1 channels affects overall ion gradients and also impairs glutamate uptake by astrocytes $[12,13]$. There are numerous theoretical analyses supporting the spatial relationship between passive and active modulation of $\left[\mathrm{K}^{+}\right]_{\mathrm{o}}$ by astrocytes and the initiation or maintenance of epileptiform activity [54-56]. Furthermore, cell depolarization and impaired ion gradients inhibit glutamate transporter function and cause transporter reversal, thus glutamate release from the cell, which could further affect neuronal excitability [57,58].

Therefore, dysfunction of astrocytic Kir4.1 channels may alter extracellular brain homeostasis and affect neuronal activity. Indeed, mutations and variations of the KCNJ10 gene encoding for Kir4.1 occur in seizure susceptible human and animal models $[14,59,60]$ including the SeSAME/EAST syndrome $[20,21,23]$. In seizure susceptible DBA mice, astrocytic Kir currents are reduced and this has been correlated with decreased $\mathrm{K}^{+}$uptake and glutamate clearance by these cells [14]. Other studies have shown Kir4.1 downregulation as well as impaired glutamate and potassium uptake when glial cells are exposed to hyperglycemic/diabetic conditions in both glial cells in culture [26] and in streptozotocin-induced diabetic animals [49]. In the present study, we found that astrocytes in hippocampal slices from diabetic mice had a depolarized membrane potential and reduced functional Kir channel activity. It is well established that astrocytes regulate extracellular $\mathrm{K}^{+}$concentration by taking up excess $\mathrm{K}^{+}$from active synaptic areas and by redistributing it to sites of lower $\mathrm{K}^{+}$concentration through the astrocytic syncytium [16,18].

When an action potential propagates, extracellular $\mathrm{K}^{+}$increases [61]. If this excess potassium is not removed, it could cause hyperexcitability, seizures and neuronal death. Therefore, we evaluated the ability of astrocytes to take up excess $\mathrm{K}^{+}$by stepping external $\mathrm{K}^{+}$from $2.5 \mathrm{mM}$ to $10 \mathrm{mM}$ and measuring the inward current generated. As predicted, we found that astrocytes from diabetic animals displayed impaired $\mathrm{K}^{+}$uptake capabilities compared with non-diabetic mice. Taken together, reduced astrocytic membrane potential, reduced Kir channel activity, and impaired $\mathrm{K}^{+}$uptake in diabetic mice could impact the ability of astrocytes to maintain extracellular ion homeostasis and consequently affect neuronal excitability.

\section{Conclusions}

In conclusion, we examined the association between CA1 pyramidal cell membrane excitability together with astrocytic Kir4.1 potassium channel function in the hippocampus using a type 2 diabetic mouse model. We found that CA1 pyramidal neurons from diabetic mice were hyperexcitable and this correlated with reduced functional Kir4.1 channel activity in astrocytes. Overall, our data provide insight into a potential Kir4.1 potassium channel-dependent mechanism that may help explain the high incidence of seizures seen in patients with uncontrolled hyperglycemia. 
Author Contributions: Conceptualization: M.J.E. and S.N.S.: Methodology: M.P.M.-G., J.B., M.J.E. and S.N.S.: Investigation: M.P.M.-G., G.M.-M., D.E.R.-A. and F.T.-B.; Writing-Original Draft Preparation: M.P.M.-G. and M.J.E.; Writing-Review \& Editing: M.P.M.-G., D.E.R.-A., S.N.S. and M.J.E.; Funding Acquisition: M.J.E. and S.N.S. All authors have read and agreed to the published version of the manuscript.

Funding: This work was supported by the following funding sources: American Diabetes Association 1-19-IBS-300, NIH-R01NS065201, NIH-G12MD007583, NIH-R25GM110513, NIH P20 GM103475-15 and Department of Education Title V PPOHA P031M105050 and Title V P031S130068.

Acknowledgments: We thank Christian Malpica, Paola López Pieraldi and Yanitza Hernández for their superior technical assistance.

Conflicts of Interest: The authors declare no conflict of interest. The funders had no role in the design of the study; in the collection, analyses, or interpretation of data; in the writing of the manuscript, or in the decision to publish the results.

\section{References}

1. Fisher, R.S.; Acevedo, C.; Arzimanoglou, A.; Bogacz, A.; Cross, J.H.; Elger, C.E.; Engel, J.; Forsgren, L.; French, J.A.; Glynn, M.; et al. ILAE Official Report: A Practical Clinical Definition of Epilepsy. Epilepsia 2014, 55, 475-482. [CrossRef] [PubMed]

2. Shorvon, S.D. The Etiologic Classification of Epilepsy. Epilepsia 2011, 52, 1052-1057. [CrossRef] [PubMed]

3. Chen, Y.; Wang, X. Association between Seizures and Diabetes Mellitus: A Comprehensive Review of Literature. Curr. Diabetes Rev. 2013, 9, 350-354.

4. Younes, S.; Cherif, Y.; Aissi, M.; Alaya, W.; Berriche, O.; Boughammoura, A.; Frih-Ayed, M.; Zantour, B.; Habib Sfar, M. Seizures and Movement Disorders Induced by Hyperglycemia without Ketosis in Elderly. Iran J. Neurol. 2014, 13, 172-176. [PubMed]

5. Grant, C.; Warlow, C. Focal Epilepsy in Diabetic Non-Ketotic Hyperglycaemia. Br. Med. J. (Clin. Res. Ed.) 1985, 290, 1204-1205. [CrossRef] [PubMed]

6. Lu, C.-L.; Chang, Y.-H.; Sun, Y.; Li, C.-Y. A Population-Based Study of Epilepsy Incidence in Association with Type 2 Diabetes and Severe Hypoglycaemia. Diabetes Res. Clin. Pract. 2018, 140, 97-106. [CrossRef]

7. Brennan, M.R.; Whitehouse, F.W. Case Study: Seizures and Hypoglycemia. Clin. Diabetes 2012, 30, $23-24$. [CrossRef]

8. Di Mario, U.; Morano, S.; Valle, E.; Pozzessere, G. Electrophysiological Alterations of the Central Nervous System in Diabetes Mellitus. Diabetes Metab. Rev. 1995, 11, 259-277. [CrossRef]

9. De Leon-Morales, L.V.D.; Jauregui-Renaud, K.; Garay-Sevilla, M.E.; Hernandez-Prado, J.; Malacara-Hernandez, J.M. Auditory Impairment in Patients with Type 2 Diabetes Mellitus. Arch. Med. Res. 2005, 36, 507-510. [CrossRef]

10. Kamal, A.; Biessels, G.J.; Gispen, W.H.; Ramakers, G.M. Synaptic Transmission Changes in the Pyramidal Cells of the Hippocampus in Streptozotocin-Induced Diabetes Mellitus in Rats. Brain Res. 2006, 1073-1074, 276-280. [CrossRef]

11. Butt, A.M.; Kalsi, A. Inwardly Rectifying Potassium Channels (Kir) in Central Nervous System Glia: A Special Role for Kir4.1 in Glial Functions. J. Cell. Mol. Med. 2006, 10, 33-44. [CrossRef] [PubMed]

12. Kucheryavykh, Y.V.; Kucheryavykh, L.Y.; Nichols, C.G.; Maldonado, H.M.; Baksi, K.; Reichenbach, A.; Skatchkov, S.N.; Eaton, M.J. Downregulation of Kir4.1 Inward Rectifying Potassium Channel Subunits by RNAi Impairs Potassium Transfer and Glutamate Uptake by Cultured Cortical Astrocytes. Glia 2007, 55, 274-281. [CrossRef] [PubMed]

13. Djukic, B.; Casper, K.B.; Philpot, B.D.; Chin, L.S.; McCarthy, K.D. Conditional Knock-out of Kir4.1 Leads to Glial Membrane Depolarization, Inhibition of Potassium and Glutamate Uptake, and Enhanced Short-Term Synaptic Potentiation. J. Neurosci. 2007, 27, 11354-11365. [CrossRef] [PubMed]

14. Inyushin, M.; Kucheryavykh, L.Y.; Kucheryavykh, Y.V.; Nichols, C.G.; Buono, R.J.; Ferraro, T.N.; Skatchkov, S.N.; Eaton, M.J. Potassium Channel Activity and Glutamate Uptake Are Impaired in Astrocytes of Seizure-Susceptible DBA/2 Mice. Epilepsia 2010, 51, 1707-1713. [CrossRef]

15. Seifert, G.; Carmignoto, G.; Steinhauser, C. Astrocyte Dysfunction in Epilepsy. Brain Res. Rev. 2010, 63, 212-221. [CrossRef]

16. Olsen, M.L.; Khakh, B.S.; Skatchkov, S.N.; Zhou, M.; Lee, C.J.; Rouach, N. New Insights on Astrocyte Ion Channels: Critical for Homeostasis and Neuron-Glia Signaling. J. Neurosci. 2015, 35, 13827-13835. [CrossRef] 
17. Seifert, G.; Huttmann, K.; Binder, D.K.; Hartmann, C.; Wyczynski, A.; Neusch, C.; Steinhauser, C. Analysis of Astroglial K+ Channel Expression in the Developing Hippocampus Reveals a Predominant Role of the Kir4.1 Subunit. J. Neurosci. 2009, 29, 7474-7488. [CrossRef]

18. Chen, K.C.; Nicholson, C. Spatial Buffering of Potassium Ions in Brain Extracellular Space. Biophys. J. 2000, 78, 2776-2797. [CrossRef]

19. Skatchkov, S.N.; Krusek, J.; Reichenbach, A.; Orkand, R.K. Potassium Buffering by Muller Cells Isolated from the Center and Periphery of the Frog Retina. Glia 1999, 27, 171-180. [CrossRef]

20. Scholl, U.I.; Choi, M.; Liu, T.; Ramaekers, V.T.; Hausler, M.G.; Grimmer, J.; Tobe, S.W.; Farhi, A.; Nelson-Williams, C.; Lifton, R.P. Seizures, Sensorineural Deafness, Ataxia, Mental Retardation, and Electrolyte Imbalance (SeSAME Syndrome) Caused by Mutations in KCNJ10. Proc. Natl. Acad. Sci. USA 2009, 106, 5842-5847. [CrossRef]

21. Bockenhauer, D.; Feather, S.; Stanescu, H.C.; Bandulik, S.; Zdebik, A.A.; Reichold, M.; Tobin, J.; Lieberer, E.; Sterner, C.; Landoure, G.; et al. Epilepsy, Ataxia, Sensorineural Deafness, Tubulopathy, and KCNJ10 Mutations. N. Engl. J. Med. 2009, 360, 1960-1970. [CrossRef] [PubMed]

22. Sala-Rabanal, M.; Kucheryavykh, L.Y.; Skatchkov, S.N.; Eaton, M.J.; Nichols, C.G. Molecular Mechanisms of EAST/SeSAME Syndrome Mutations in Kir4.1 (KCNJ10). J. Biol. Chem. 2010, 285, 36040-36048. [CrossRef]

23. Mir, A.; Chaudhary, M.; Alkhaldi, H.; Alhazmi, R.; Albaradie, R.; Housawi, Y. Epilepsy in Patients with EAST Syndrome Caused by Mutation in the KCNJ10. Brain Dev. 2019, 41, 706-715. [CrossRef] [PubMed]

24. Singh, B.M.; Strobos, R.J. Epilepsia Partialis Continua Associated with Nonketotic Hyperglycemia: Clinical and Biochemical Profile of 21 Patients. Ann. Neurol. 1980, 8, 155-160. [CrossRef] [PubMed]

25. Kamha, A. Non Ketotic Hyperosmolar Hyperglycemia Presenting as Epilepsia Partialis Continua: An Unusual Presentation of a Common Disorder. Libyan J. Med. 2008, 3, 111-112. [CrossRef] [PubMed]

26. Rivera-Aponte, D.E.; Mendez-Gonzalez, M.P.; Rivera-Pagan, A.F.; Kucheryavykh, Y.V.; Kucheryavykh, L.Y.; Skatchkov, S.N.; Eaton, M.J. Hyperglycemia Reduces Functional Expression of Astrocytic Kir4.1 Channels and Glial Glutamate Uptake. Neuroscience 2015, 310, 216-223. [CrossRef] [PubMed]

27. Hummel, K.P.; Dickie, M.M.; Coleman, D.L. Diabetes, a New Mutation in the Mouse. Science 1966, 153, 1127-1128. [CrossRef] [PubMed]

28. Hibino, H.; Fujita, A.; Iwai, K.; Yamada, M.; Kurachi, Y. Differential Assembly of Inwardly Rectifying K+ Channel Subunits, Kir4.1 and Kir5.1, in Brain Astrocytes. J. Biol. Chem. 2004, 279, 44065-44073. [CrossRef]

29. Fan, H.; Huang, A.; Villegas, C.; Wright, J.A. The R1 Component of Mammalian Ribonucleotide Reductase Has Malignancy-Suppressing Activity as Demonstrated by Gene Transfer Experiments. Proc. Natl. Acad. Sci. USA 1997, 94, 13181-13186. [CrossRef]

30. Zhou, M.; Schools, G.P.; Kimelberg, H.K. Development of GLAST(+) Astrocytes and NG2(+) Glia in Rat Hippocampus CA1: Mature Astrocytes Are Electrophysiologically Passive. J. Neurophysiol. 2006, 95, $134-143$. [CrossRef]

31. Battefeld, A.; Klooster, J.; Kole, M.H.P. Myelinating Satellite Oligodendrocytes Are Integrated in a Glial Syncytium Constraining Neuronal High-Frequency Activity. Nat. Commun. 2016, 7. [CrossRef] [PubMed]

32. Maldonado, P.P.; Velez-Fort, M.; Levavasseur, F.; Angulo, M.C. Oligodendrocyte Precursor Cells Are Accurate Sensors of Local K+ in Mature Gray Matter. J. Neurosci. 2013, 33, 2432-2442. [CrossRef] [PubMed]

33. Feliciano, P.; Andrade, R.; Bykhovskaia, M. Synapsin II and Rab3a Cooperate in the Regulation of Epileptic and Synaptic Activity in the CA1 Region of the Hippocampus. J. Neurosci. 2013, 33, 18319-18330. [CrossRef] [PubMed]

34. Verrotti, A.; Scaparrotta, A.; Olivieri, C.; Chiarelli, F. Seizures and Type 1 Diabetes Mellitus: Current State of Knowledge. Eur. J. Endocrinol. 2012, 167, 749-758. [CrossRef] [PubMed]

35. Moien-Afshari, F.; Tellez-Zenteno, J.F. Occipital Seizures Induced by Hyperglycemia: A Case Report and Review of Literature. Seizure 2009, 18, 382-385. [CrossRef] [PubMed]

36. Margineanu, D.G.; Niespodziany, I.; Wulfert, E. Hippocampal Slices from Long-Term Streptozotocin-Injected Rats Are Prone to Epileptiform Responses. Neurosci. Lett. 1998, 252, 183-186. [CrossRef]

37. Huang, C.W.; Cheng, J.T.; Tsai, J.J.; Wu, S.N.; Huang, C.C. Diabetic Hyperglycemia Aggravates Seizures and Status Epilepticus-Induced Hippocampal Damage. Neurotox. Res. 2009, 15, 71-81. [CrossRef]

38. Schwechter, E.M.; Veliskova, J.; Velisek, L. Correlation between Extracellular Glucose and Seizure Susceptibility in Adult Rats. Ann. Neurol. 2003, 53, 91-101. [CrossRef] 
39. Lin, C.W.; Sim, S.; Ainsworth, A.; Okada, M.; Kelsch, W.; Lois, C. Genetically Increased Cell-Intrinsic Excitability Enhances Neuronal Integration into Adult Brain Circuits. Neuron 2010, 65, 32-39. [CrossRef]

40. Narla, C.; Scidmore, T.; Jeong, J.; Everest, M.; Chidiac, P.; Poulter, M.O. A Switch in G Protein Coupling for Type 1 Corticotropin-Releasing Factor Receptors Promotes Excitability in Epileptic Brains. Sci. Signal. 2016, 9, ra60. [CrossRef]

41. Howlett, E.; Lin, C.C.; Lavery, W.; Stern, M. A PI3-Kinase-Mediated Negative Feedback Regulates Neuronal Excitability. PLoS Genet. 2008, 4, e1000277. [CrossRef] [PubMed]

42. Arakaki, X.; Foster, H.; Su, L.; Do, H.; Wain, A.J.; Fonteh, A.N.; Zhou, F.; Harrington, M.G. Extracellular Sodium Modulates the Excitability of Cultured Hippocampal Pyramidal Cells. Brain Res. 2011, 1401, 85-94. [CrossRef] [PubMed]

43. Toni, N.; Buchs, P.A.; Nikonenko, I.; Bron, C.R.; Muller, D. LTP Promotes Formation of Multiple Spine Synapses between a Single Axon Terminal and a Dendrite. Nature 1999, 402, 421-425. [CrossRef] [PubMed]

44. Bacci, A.; Verderio, C.; Pravettoni, E.; Matteoli, M. The Role of Glial Cells in Synaptic Function. Philos. Trans. R. Soc. Lond. B Biol. Sci. 1999, 354, 403-409. [CrossRef]

45. Jayanarayanan, S.; Smijin, S.; Peeyush, K.T.; Anju, T.R.; Paulose, C.S. NMDA and AMPA Receptor Mediated Excitotoxicity in Cerebral Cortex of Streptozotocin Induced Diabetic Rat: Ameliorating Effects of Curcumin. Chem. Biol. Interact. 2013, 201, 39-48. [CrossRef]

46. Bach, E.C.; Halmos, K.C.; Smith, B.N. Enhanced NMDA Receptor-Mediated Modulation of Excitatory Neurotransmission in the Dorsal Vagal Complex of Streptozotocin-Treated, Chronically Hyperglycemic Mice. PLoS ONE 2015, 10, e0121022. [CrossRef]

47. Wanrooy, B.J.; Kumar, K.P.; Wen, S.W.; Qin, C.X.; Ritchie, R.H.; Wong, C.H.Y. Distinct Contributions of Hyperglycemia and High-Fat Feeding in Metabolic Syndrome-Induced Neuroinflammation. J. Neuroinflamm. 2018, 15, 293. [CrossRef]

48. Bogdanov, P.; Corraliza, L.; Villena, J.A.; Carvalho, A.R.; Garcia-Arumí, J.; Ramos, D.; Ruberte, J.; Simó, R.; Hernández, C. The Db/Db Mouse: A Useful Model for the Study of Diabetic Retinal Neurodegeneration. PLOS ONE 2014, 9, e97302. [CrossRef]

49. Pannicke, T.; Iandiev, I.; Wurm, A.; Uckermann, O.; vom Hagen, F.; Reichenbach, A.; Wiedemann, P.; Hammes, H.P.; Bringmann, A. Diabetes Alters Osmotic Swelling Characteristics and Membrane Conductance of Glial Cells in Rat Retina. Diabetes 2006, 55, 633-639. [CrossRef]

50. Kucheryavykh, Y.V.; Pearson, W.L.; Kurata, H.T.; Eaton, M.J.; Skatchkov, S.N.; Nichols, C.G. Polyamine Permeation and Rectification of Kir4.1 Channels. Channels 2007, 1, 172-178. [CrossRef]

51. Thomzig, A.; Wenzel, M.; Karschin, C.; Eaton, M.J.; Skatchkov, S.N.; Karschin, A.; Veh, R.W. Kir6.1 is the principal pore-forming subunit of astrocyte but not neuronal plasma membrane K-ATP channels. Mol. Cell. Neurosci. 2001, 18, 671-690. [CrossRef] [PubMed]

52. Kucheryavykh, L.Y.; Kucheryavykh, Y.V.; Inyushin, M.; Shuba, Y.M.; Sanabria, P.; Cubano, L.A.; Skatchkov, S.N.; Eaton, M.J. Ischemia Increases TREK-2 Channel Expression in Astrocytes: Relevance to Glutamate Clearance. Open Neurosci. J. 2009, 3, 40-47. [CrossRef] [PubMed]

53. Zhou, M.; Xu, G.; Xie, M.; Zhang, X.; Schools, G.P.; Ma, L.; Kimelberg, H.K.; Chen, H. TWIK-1 and TREK-1 Are Potassium Channels Contributing Significantly to Astrocyte Passive Conductance in Rat Hippocampal Slices. J. Neurosci. 2009, 29, 8551-8564. [CrossRef] [PubMed]

54. Sibille, J.; Pannasch, U.; Rouach, N. Astroglial Potassium Clearance Contributes to Short-Term Plasticity of Synaptically Evoked Currents at the Tripartite Synapse. J. Physiol. 2014, 592 Pt 1, 87-102. [CrossRef]

55. Witthoft, A.; Filosa, J.A.; Karniadakis, G.E. Potassium Buffering in the Neurovascular Unit: Models and Sensitivity Analysis. Biophys. J. 2013, 105, 2046-2054. [CrossRef]

56. Du, M.; Li, J.; Chen, L.; Yu, Y.; Wu, Y. Astrocytic Kir4.1 Channels and Gap Junctions Account for Spontaneous Epileptic Seizure. PLoS Comput. Biol. 2018, 14, e1005877. [CrossRef]

57. Mennerick, S.; Shen, W.; Xu, W.; Benz, A.; Tanaka, K.; Shimamoto, K.; Isenberg, K.E.; Krause, J.E.; Zorumski, C.F. Substrate Turnover by Transporters Curtails Synaptic Glutamate Transients. J. Neurosci. 1999, 19, 9242-9251. [CrossRef]

58. Bordey, A.; Sontheimer, H. Modulation of Glutamatergic Transmission by Bergmann Glial Cells in Rat Cerebellum in Situ. J. Neurophysiol. 2003, 89, 979-988. [CrossRef] 
59. Ferraro, T.N.; Golden, G.T.; Smith, G.G.; Martin, J.F.; Lohoff, F.W.; Gieringer, T.A.; Zamboni, D.; Schwebel, C.L.; Press, D.M.; Kratzer, S.O.; et al. Fine Mapping of a Seizure Susceptibility Locus on Mouse Chromosome 1: Nomination of Kcnj10 as a Causative Gene. Mamm. Genome 2004, 15, 239-251. [CrossRef]

60. Buono, R.J.; Lohoff, F.W.; Sander, T.; Sperling, M.R.; O'Connor, M.J.; Dlugos, D.J.; Ryan, S.G.; Golden, G.T.; Zhao, H.; Scattergood, T.M.; et al. Association between Variation in the Human KCNJ10 Potassium Ion Channel Gene and Seizure Susceptibility. Epilepsy Res. 2004, 58, 175-183. [CrossRef]

61. Heinemann, U.; Lux, H.D. Ceiling of Stimulus Induced Rises in Extracellular Potassium Concentration in the Cerebral Cortex of Cat. Brain Res. 1977, 120, 231-249. [CrossRef]

(C) 2020 by the authors. Licensee MDPI, Basel, Switzerland. This article is an open access article distributed under the terms and conditions of the Creative Commons Attribution (CC BY) license (http://creativecommons.org/licenses/by/4.0/). 